\title{
TRANSFER PELATIHAN ALUMNI PENDIDIKAN DAN PELATIHAN PENELITIAN TINDAKAN KELAS (PTK) BALAI DIKLAT KEAGAMAAN DENPASAR
}

\section{TRANSFER OF TRAINING ALUMNI OF TECHNICAL SUBSTANTIVE IN CLASSROOM ACTION RESEARCH OF BALAI DIKLAT KEAGAMAAN DENPASAR}

\author{
Amalia Puspayanti \\ Balai Diklat Keagamaan Denpasar, Kementerian Agama \\ Email: amalia_bdk11@yahoo.com
}

Naskah Diterima: 06 Maret 2019; Direvisi: 28 Juli 2019; Disetujui: 30 Juli 2019

\begin{abstract}
This study is qualitative descriptive ex post facto, the goal of this study was to achieve a training's review by training alumni for technical substantive in classroom action research at Balai Diklat Keagamaan Denpasar. The population of this study was 3 members of the training alumni. The Data were collected by interview and documentation. The collected data will be analyzed in analysis procedure of qualitative data and also included in reducing, providing, and concluding/verifying data. The study shows that training transfer by alumni has applied by continuing proposal resulted in the training. Training transfer was influenced by characteristic of training members (cognitive ability, motivation, self-efficacy, and orientation in training benefit), training design, and work environment. In a practice, there was some members applying immediately after the training (less or up to 6 months) and also there was along one year. This training transfer was requires an arranged condition through realization of continuous action plan completely and it will proceed to a seminar of the class action study. Based on the study conclusion, it was recommended to be more applied training transfer by training alumni of technical substantive in class action study. Widyaiswara should be guided and motivated to alumni for implementing output training in the real action.
\end{abstract}

Keywords: Balai Diklat Keagamaan Denpasar; Classroom Action Research (CAR); Training alumni; Transfer of training

\begin{abstract}
Abstrak
Penelitian ini merupakan penelitian deskriptif kualitatif ex post facto yang bertujuan untuk memperoleh gambaran tentang transfer pelatihan oleh alumni Pendidikan dan Pelatihan (Diklat) Teknis Substantif Penelitian Tindakan Kelas (PTK) Balai Diklat Keagamaan Denpasar. Subjek penelitian mengambil 3 orang alumni diklat Teknis Substantif PTK. Pengumpulan data dilakukan dengan teknik wawancara dan dokumentasi. Data kemudian dianalisis menggunakan prosedur analisis data kualitatif meliputi reduksi data, penyajian data, dan penyimpulan/verifikasi. Hasil penelitian menunjukkan bahwa transfer pelatihan oleh alumni dilakukan dengan melanjutkan proposal yang dibuat selama diklat, yang pada praktiknya ada yang dilaksanakan segera setelah diklat (kurang dari atau sampai dengan 6 bulan) dan ada yang sampai 1 tahun. Transfer pelatihan dipengaruhi oleh karakteristik peserta diklat (yang meliputi kemampuan kognitif, motivasi, efikasi diri, dan orientasi manfaat diklat), desain pelatihan, dan lingkungan kerja. Maka dari itu perlu dikondisikan melalui realisasi Rencana Tindak Lanjut (RTL) secara maksimal dan terus lanjut sampai ke pelaksanaan seminar hasil PTK. Sejalan dengan simpulan penelitian, direkomendasikan untuk lebih menggiatkan transfer pelatihan oleh alumni Diklat Teknis Substantif PTK. Widyaiswara hendaknya terus memberikan bimbingan dan motivasi kepada para alumni untuk menindaklanjuti hasil diklat.
\end{abstract}

Kata Kunci: Alumni diklat; Balai Diklat Keagamaan Denpasar; Penelitian Tindakan Kelas (PTK); Transfer pelatihan 


\section{PENDAHULUAN}

Balai Diklat Keagamaan (BDK) Denpasar sebagai lembaga yang berwenang melaksanakan Pendidikan dan Pelatihan (Diklat) di wilayah kerja lingkup Kementerian Agama Provinsi Bali, Nusa Tenggara Barat, dan Nusa Tenggara Timur, ikut berperan dalam upaya peningkatan kompetensi dan profesionalisme guru. Jenis program diklat yang diselenggarakan diutamakan pada prioritas kebutuhan di wilayah kerja. Khusus yang diperuntukkan bagi guru, mengambil fokus pada substansi keguruan baik berhubungan dengan tugas utama mengajar maupun kompetensi pendukung tugas guru.

Salah satu jenis diklat teknis pendidikan yang diselenggarakan oleh BDK Denpasar adalah Diklat Teknis Substantif Penelitian Tindakan Kelas (PTK). Diklat ini menjadi satu kebutuhan guru dikarenakan kewajiban publikasi ilmiah yang harus dipenuhi untuk kenaikan pangkat sekaligus menunjang perbaikan proses pembelajaran di kelas. Meski PTK adalah bukan satu-satunya publikasi ilmiah yang harus dibuat oleh guru tetapi tetap menjadi penting karena PTK lah jenis penelitian yang sangat memungkinkan untuk dilakukan di sela keseharian mengajar dan berhubungan langsung dengan tugas utama guru. Diklat Teknis Substantif PTK memiliki tujuan membekali pengetahuan, keterampilan serta membangun sikap positif guru dalam melaksanakan PTK. Struktur kurikulum berisikan target pada penguasaan kompetensi menyusun proposal, perangkat yang diperlukan untuk pelaksanaan siklus, tata cara pengolahan data sampai mekanisme pembuatan laporan.

Pada akhir diklat, setiap peserta menghasilkan proposal PTK beserta perangkat yang dibutuhkan untuk pelaksanaan siklus. Meskipun belum sempurna, paling tidak hasil kerja selama diklat tersebut menjadi titik permulaan bagi peserta untuk melakukan PTK. Pasca diklat usai, peserta atau dalam hal ini alumni diklat dapat menyempurnakan kembali proposal maupun perangkat yang telah dibuat serta merencanakan langkah selanjutnya sesuai langkah kerja sebuah penelitian. Bagaimana cara melaksanakan PTK ke dalam siklus telah dipelajari saat diklat, juga cara mengolah data dan membuat laporan hasil PTK. Jadi seyogyanya alumni diklat dapat melakukan PTK secara mandiri berbekal pengetahuan dan keterampilan yang diperoleh selama diklat.

Efektivitas diklat dapat terbukti jika alumni mengimplementasikan ilmu dan keterampilannya setelah kembali ke tempat tugas masing-masing. Sesuai dengan substansi PTK, tentu implementasi yang terdekat dapat diwujudkan dalam bentuk PTK. Bentuk pengimplementasian ilmu dan keterampilan melalui kegiatan PTK seperti ini dikenal juga dengan istilah transfer pelatihan. Transfer pelatihan adalah penerapan pengetahuan, sikap, dan keterampilan yang dilatihkan selama diklat ke dalam lingkungan kerja melalui aktivitas yang efektif dan berkelanjutan. Banyak alternatif kegiatan yang dapat dilakukan sebagai bentuk transfer pelatihan oleh alumni diklat. Khusus dalam penelitian ini, peneliti fokuskan pada kegiatan PTK yang sesuai dengan rancangan penelitian sebagaimana tertuang dalam proposal masing-masing alumni.

Wujud transfer pelatihan ini sejalan kiranya dengan konsep Rencana Tindak Lanjut (RTL). RTL merupakan salah satu mata diklat penunjang yang diatur oleh Pusat Pendidikan dan Pelatihan (Pusdiklat) Tenaga Teknis Pendidikan dan Keagamaan termuat dalam kurikulum Diklat Teknis Substantif PTK. Mata diklat RTL mewajibkan alumni untuk melakukan tindak lanjut setelah mengikuti diklat. Melalui RTL, Pusdiklat dan Balai Diklat ingin menguatkan bahwa efektivitas penyelenggaraan diklat tidak hanya terletak pada maksimalnya proses pelaksanaan tetapi juga kinerja alumni yang bisa ditunjukkan sebagai keberlanjutan dari hasil mengikuti diklat. Ada keterkaitan antara RTL dengan transfer pelatihan yang dapat dicermati di sini, di mana jika alumni melaksanakan RTL sudah pasti alumni tersebut melakukan transfer pelatihan, sebaliknya jika alumni melakukan transfer pelatihan maka sudah pasti yang bersangkutan merealisasikan RTL.

Penyelenggaraan Diklat Teknis Substantif PTK sesungguhnya ikut menjawab permasalahan yang umum terjadi pada guru. Sebagian besar guru kesulitan membuat publikasi ilmiah seperti PTK sehingga mandek di golongan IV/a (Hadriyanto dalam Wahyuningtyas \& Ratnawati, 2018). Golongan 
IV/a bahkan dari III/d memang disyaratkan wajib untuk membuat karya tulis ilmiah atau publikasi ilmiah berupa penelitian. Oleh karena itu, sejalan kiranya perhatian besar BDK Denpasar dalam mendorong semangat dan membekali kemampuan guru untuk melaksanakan PTK karena PTK merupakan penelitian yang paling mudah bagi guru. Minimal guru-guru yang berkesempatan mengikuti diklat diharapkan tidak akan mengalami permasalahan yang serupa. Bahkan lebih jauh diharapkan alumni dapat mengimbaskan pengetahuan, keterampilan maupun pengalaman melakukan PTK tersebut ke teman sejawat guru yang lain sehingga semakin banyak guru yang tidak mengalami permasalahan serupa.

Namun demikian, pada kajian terdahulu banyak diungkap bahwa alumni diklat memiliki kecenderungan tidak segera mengimplementasikan hasil diklat sekembalinya ke tempat tugas atau bahkan ada yang tidak menerapkan dan memanfaatkannya sama sekali. Transfer pelatihan menjadi isu penting yang sedari lama dibahas dalam kajian konteks organisasi. Berbagai ulasan maupun penelitian muncul sejak ditemukannya model transfer pelatihan oleh Baldwin dan Ford di tahun 1988. Saks (2002) mengungkap bahwa $40 \%$ peserta pelatihan tidak segera mengimplementasikan hasil pelatihan sekembalinya ke tempat kerja, bahkan nilai $40 \%$ naik mendekati $70 \%$ setelah 1 tahun. Banyak program pelatihan yang tidak efektif sehingga tidak mampu meningkatkan kualitas dan produktivitas tenaga kerja yang yang merupakan alumni pelatihan dimaksud (Hariyanto, Purnomo \& Bawono, 2011). Hal serupa juga diungkap oleh Grosman \& Salas (2011) yang mengatakan bahwa meskipun sudah miliaran dolar yang dikeluarkan oleh lembaga, namun kompetensi-kompetensi yang dilatihkan dalam pelatihan pada akhirnya gagal ditransfer ke tempat kerja. Hal tersebut dipengaruhi oleh berbagai faktor dalam transfer pelatihan sebagaimana yang diungkap oleh Baldwin dan Ford. Broad \& Newstorm (dalam Saks \& Burke, 2012) juga menyatakan bahwa hanya sedikit dari apa yang telah dipelajari dalam pelatihan, diaplikasikan dalam pekerjaan.

Kemaksimalan pengimplementasian hasil diklat atau yang diistilahkan dengan transfer pelatihan memang dipengaruhi oleh beberapa faktor. Sebagaimana diungkap dalam penelitian Kimbal (2015) yang menyatakan bahwa efikasi diri, lingkungan kerja, dan dukungan atasan sangat mempengaruhi transfer pelatihan. Ardaneswari (2016) melalui penelitiannya juga mengungkap hal yang hampir serupa di mana dikatakan bahwa transfer of training dipengaruhi oleh faktor internal dan eksternal. Faktor internal meliputi fasilitas, dukungan pimpinan dan rekan kerja, reward dan punishment. Sedangkan faktor eksternal meliputi kebijakan pemerintah pusat dan daerah serta teknologi.

Mencermati pentingnya Diklat Teknis Substantif PTK bagi guru, kemudian adanya keterkaitan antara RTL yang menjadi tuntutan pada alumni untuk menindaklanjuti hasil diklat dengan konsep transfer pelatihan, dihubungkan juga dengan kajian terdahulu, maka tepat kiranya bagi peneliti untuk memfokuskan penelitian pada transfer pelatihan alumni Diklat Teknis Substantif PTK. Sebagai data awal, peneliti mengumpulkan informasi dari 3 orang alumni yang bertugas di kota Denpasar. Ketiga alumni tersebut, satu orang sempat meminta bimbingan untuk membenahi proposalnya dan persiapan siklus (seminggu setelah diklat selesai). Satu orang lagi meminta bimbingan saat melaksanakan siklus (sebulan setelah diklat) dan bagaimana mengolah data hasil siklus bahkan sampai pada penulisan bab IV ( 3 bulan setelah diklat). Satu orang lagi mengakui belum sempat melakukan kerja apapun terkait hasil diklat dikarenakan kesibukan tugas tambahan sebagai pengelola keuangan di madrasahnya (3 bulan setelah diklat). Secara spontan ketiga alumni mengakui ada kendala di pengaturan waktu, kesibukan tugas tambahan, ketersediaan fasilitas, dan lain sebagainya. Atas dasar ini maka peneliti bertujuan ingin menyelisik lebih lanjut untuk memperoleh gambaran tentang transfer pelatihan oleh alumni Diklat Teknis Substantif PTK. Rumusan masalah yang diajukan dalam penelitian ini adalah Bagaimana transfer pelatihan alumni Diklat Teknis Substantif Penelitian Tindakan Kelas BDK Denpasar?.

Berikut dijelaskan beberapa konsep yang mendukung untuk membahas permasalahan penelitian. 


\section{Transfer Pelatihan}

Implementasi hasil diklat yang berupa pengetahuan, sikap, dan keterampilan oleh para peserta sekembalinya ke tempat tugas masingmasing dikenal dengan istilah transfer of training atau transfer pelatihan. Baldwin \& Ford (1988) mendefinisikan transfer pelatihan sebagai penerapan pengetahuan, sikap, dan keterampilan yang dipelajari dan dilatihkan selama diklat ke dalam situasi kerja, dilakukan secara kontinu dan konsisten dalam rentang waktu tertentu. Noe et al. dalam Kimbal (2015) juga mengungkapkan bahwa transfer pelatihan adalah sejauh mana hasil pelatihan baik pengetahuan, keterampilan, dan sikap belajar diterapkan dalam pekerjaan. Dari pengertian ini maka transfer pelatihan dapat diartikan sebagai sejauh mana peserta menguasai pengetahuan dan keterampilan yang dilatihkan selama diklat, kemudian mampu menerapkannya di lingkungan kerja masing-masing.

Transfer pelatihan dipengaruhi oleh tiga faktor yakni karakteristik peserta, desain pelatihan, dan lingkungan kerja. Ketiga faktor ini berdampak langsung pada proses belajar dan retensi pelatihan. Penelitian Hastari (2013) mengungkap bahwa retensi pelatihan pada alumni belum tentu maksimal $100 \%$, bisa jadi hanya sebesar $70-85 \%$.

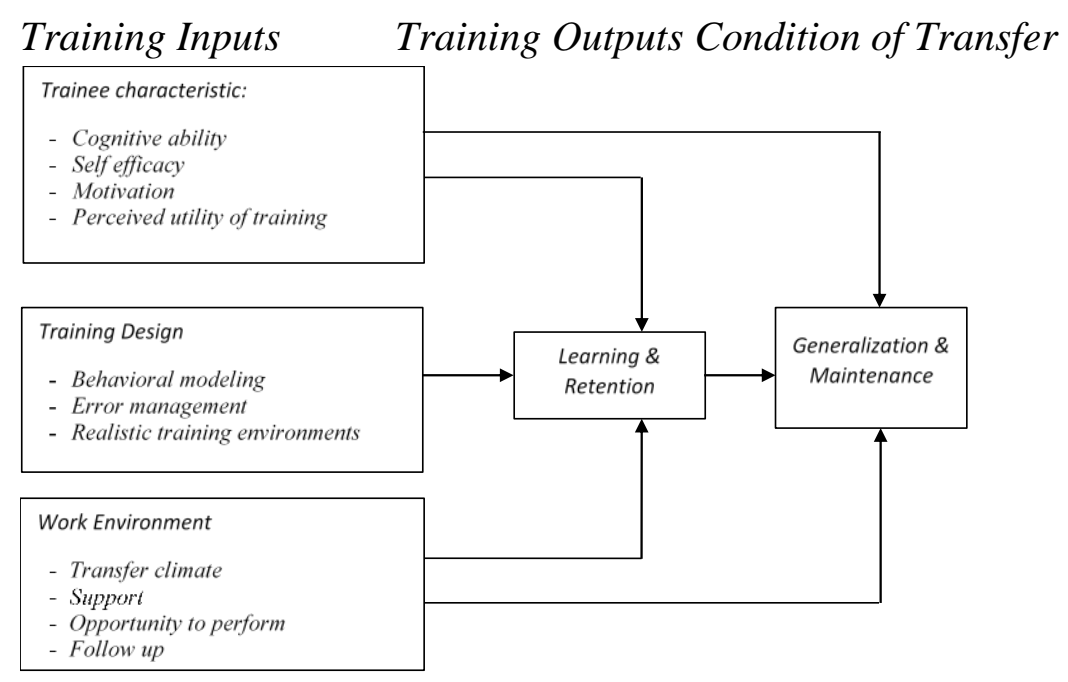

Gambar 1. Model transfer pelatihan (Baldwin \& Ford, 1988)

Ada beberapa jenis transfer pelatihan sebagaimana yang dikemukakan oleh Kaswan dalam Ardaneswari (2016), diantaranya yaitu (a) transfer positif, jika hasil diklat berdampak positif pada peningkatan kinerja alumni; (b) transfer nol, jika hasil diklat tidak berdampak sama sekali kepada kinerja alumni; (c) transfer negatif, jika hasil diklat justru berdampak negatif atau menyebabkan menurunnya kinerja alumni; (d) transfer dekat, yakni penerapan hasil diklat dengan sedikit penyesuaian dan modifikasi sesuai situasi kerja yang sesungguhnya di tempat tugas, dalam jangka waktu yang tidak lama setelah Diklat usai; (e) transfer jauh, mengembangkan dan memperluas manfaat hasil diklat dengan cara baru atau yang lebih kreatif sesuai kebutuhan sewaktu-waktu di lingkungan kerja.

Transfer pelatihan alumni Diklat Teknis Substantif PTK yang dimaksud dalam penelitian ini adalah kegiatan penelitian yang dilakukan secara mandiri oleh alumni sekembalinya ke tempat tugas, mengacu pada proposal PTK yang telah dibuat saat diklat. Kegiatan penelitian ini meliputi pelaksanaan siklus, pengolahan data, pembuatan laporan, dan pelaksanaan seminar laporan hasil PTK. Pelaksanaan siklus, pengolahan data, dan pembuatan laporan, yang baru dipelajari sebatas lewat penjelasan dan contoh-contoh saat diklat, tentu memerlukan pemahaman mengkhusus pada masing-masing alumni untuk bisa menerapkannya sesuai kondisi dan kebutuhan masing-masing. Sedangkan untuk pelaksanaan seminar juga akan sangat bergantung pada dukungan di lingkungan kerja masing-masing alumni. Sehingga akan sangat dimungkinkan capaian transfer pelatihan alumni akan berbedabeda dari segi ketuntasan maupun rentang waktu pelaksanaannya. 


\section{Diklat Teknis Substantif PTK}

Diklat sebagai salah satu cara untuk menciptakan SDM aparatur yang profesional, menjadi prioritas program yang dibutuhkan di lingkungan birokrasi. Meningkatnya tuntutan atas kinerja aparatur saat ini, mengharuskan perubahan sistem kerja yang didasarkan atas kompetensi. Diklat adalah alternatif yang dapat menjembatani tuntutan tersebut. Sejalan dengan pengertian Diklat itu sendiri yaitu penyelenggaraan pembelajaran dan pelatihan dalam rangka mengembangkan kompetensi pegawai sesuai persyaratan jabatan masingmasing pada Kementerian Agama yang dilaksanakan paling sedikit 40 jam pelajaran, dengan durasi tiap jam pelajaran adalah 45 menit (Kemenag, 2015).

Diklat Teknis Substantif adalah salah satu jenis diklat yang banyak diprioritaskan oleh BDK Denpasar, karena sifatnya membekali pada penguasaan kompetensi tertentu sesuai pelaksanaan tugas aparatur. Diklat Teknis Substantif bertujuan membekali pengetahuan dan keterampilan yang bersifat substantif yang dibutuhkan oleh seorang aparatur dalam melaksanakan tugas dan tanggung jawabnya secara kompeten dan profesional (Kemenag, 2015). Kurikulum Diklat Teknis Substantif yang diperuntukkan bagi guru, mengacu pada standar kompetensi jabatan guru yakni berhubungan dengan tugas utama mengajar, tugas tambahan, maupun pendukung tugas guru. Salah satu di antara standar kompetensi yang ada adalah melakukan tindakan reflektif untuk peningkatan kualitas pembelajaran (Depdiknas, 2007). Tindakan reflektif yang dimaksud dapat dikembangkan salah satunya melalui PTK. Tidak hanya bermanfaat untuk perbaikan proses pembelajaran tetapi juga mengasah kemampuan ilmiah guru dalam melakukan sebuah penelitian dan menyusun laporan karya tulis ilmiah.

Diklat Teknis Substantif PTK memiliki tujuan membekali pengetahuan dan keterampilan guru dalam melakukan PTK yang memang dibutuhkan untuk pengembangan profesi dan peningkatan kualitas pembelajaran. Kurikulumnya terdiri atas 50 jam pelajaran (JP) dengan struktur kurikulum mata diklat kelompok inti terdiri atas mata diklat konsep PTK (2 JP), proposal PTK (7JP), instrumen
PTK (7 JP), praktik Pelaksanaan PTK (8 JP), pengolahan data hasil PTK (7 JP), penyusunan laporan hasil PTK (7 JP), dan Rencana Tindak Lanjut (RTL).

Sebagaimana yang telah dijelaskan bahwa pada Diklat Teknis Substantif PTK ada tagihan yang berupa RTL. RTL adalah bentuk nyata implementasi keterampilan peserta diklat yang dirancang untuk dilakukan setelah diklat sekembalinya ke tempat kerja (Pusdiklat Tenaga Teknis Pendidikan dan Keagamaan, 2018). Rancangan RTL disusun oleh peserta bersama Widyaiswara pembimbing (biasanya Widyaiswara pengampu mata diklat inti) mengacu pada indikator-indikator mata diklat inti dan harus dilaporkan ke Balai Diklat jika sudah terealisasi.

Pada Diklat Teknis Substantif PTK, Widyaiswara mengarahkan peserta untuk merancang RTL dalam bentuk pelaksanaan siklus I. Hal ini dikarenakan peserta sudah memiliki proposal PTK beserta perangkat siklus I di akhir kegiatan diklat. Sehingga peserta tinggal menyempurnakan dan melengkapinya setelah kembali ke tempat tugas. Mata diklat inti yaitu proposal PTK, instrumen PTK, dan praktik pelaksanaan PTK, telah diarahkan pada penguasaan kompetensi untuk dapat melaksanakan kegiatan tersebut. Sedangkan mata diklat lainnya yakni pengolahan data dan penyusunan laporan hasil PTK dimaksudkan untuk membekali kompetensi peserta agar dapat melanjutkan kegiatan penelitian sampai ke pengolahan data dan pembuatan laporan, namun tidak menjadi tagihan RTL dan tidak dilaporkan ke BDK Denpasar. Sehingga penerbitan sertifikat diklat yang menunggu laporan realisasi RTL dibatasi waktunya sebatas menunggu laporan pelaksanaan siklus saja. Hal ini terkadang menjadi penyebab tidak tuntasnya penelitian yang dilakukan oleh para alumni. Tidak adanya tuntutan atau tagihan laporan hasil PTK, membuat beberapa alumni yang tidak meneruskan kegiatan dimaksud secara mandiri dan konsisten.

\section{METODOLOGI}

Penelitian ini merupakan penelitian deskriptif kualitatif ex post facto. Penelitian deskriptif bertujuan membuat deskripsi, gambaran atau lukisan secara sistematis, faktual 
dan akurat mengenai fakta-fakta, sifat-sifat serta hubungan antar fenomena yang diselidiki. Paradigma dari penelitian kualitatif ini, memandang realitas sosial sebagai sesuatu yang holistik atau utuh, kompleks, dinamis dan penuh makna. Melalui data yang mendalam, akan diungkap makna yang terkandung dibalik data tersebut (Sugiyono, 2011). Analisis ex post facto dimaksudkan meneliti peristiwa yang telah terjadi dengan cara merunut ke belakang dan jika dimungkinkan bertujuan melacak faktor penyebab terjadinya peristiwa yang diteliti. Identifikasi dan deskripsi atas fenomena yang terjadi akan dilakukan dengan apa adanya, tanpa ada unsur rekayasa oleh peneliti.

Penelitian ini dilaksanakan pada wilayah kerja BDK Denpasar dengan sebaran alumni yang dipilih berada di Kota Denpasar dan Kabupaten Lombok Utara. Lokasi tersebut dipilih karena memang DDWK PTK yang sudah pernah terlaksana di antaranya di Kota Denpasar dan Kabupaten Lombok Utara pada tahun 2017. Alasan memilih kedua lokasi tersebut dikarenakan melihat jarak waktu pelaksanaan tahun 2017 ke tahun 2018, ada rentang waktu yang cukup untuk bisa menganalisis transfer pelatihan oleh para alumni. Selain didukung alasan bahwa peneliti juga terlibat dalam kegiatan Diklat tersebut sehingga bisa lebih mudah untuk menjalin komunikasi dengan para alumni sebagai informan yang dibutuhkan dalam rangka pengumpulan data.

Subjek dalam penelitian ini adalah alumni DDWK PTK sebanyak 3 orang dengan rincian sebagai berikut.

Tabel 1. Komposisi Subjek Penelitian

\begin{tabular}{|c|c|c|c|c|c|}
\hline No & Informan & $\begin{array}{c}\text { Jenis } \\
\text { Kelamin }\end{array}$ & Golongan & $\begin{array}{l}\text { Asal Sekolah/ } \\
\text { Madrasah }\end{array}$ & $\begin{array}{c}\text { Jenis Diklat Teknis Substantif } \\
\text { PTK yang diikuti }\end{array}$ \\
\hline 1 & SD & $\mathrm{P}$ & IIIb & MIN Denpasar & $\begin{array}{c}\text { DDWK PTK Kota Denpasar } \\
\text { (Februari 2017) }\end{array}$ \\
\hline 2 & NM & $\mathrm{P}$ & IIId & SMPN 1 Pemenang & $\begin{array}{l}\text { DDWK PTK Kab. Lombok } \\
\text { Utara (Oktober 2017) }\end{array}$ \\
\hline 3 & WS & $\mathrm{L}$ & IIIc & SDN 2 Mumbul Sari & $\begin{array}{l}\text { DDWK PTK Kab. Lombok } \\
\text { Utara (Oktober 2017) }\end{array}$ \\
\hline & \multicolumn{4}{|c|}{ Banyak informan } & 3 Orang \\
\hline
\end{tabular}

Subjek dalam penelitian ini dipilih secara purposive yakni dipilih dengan pertimbangan dan tujuan tertentu. Dari 80 orang alumni yang terdiri atas guru mata pelajaran pendidikan agama Islam dan guru madrasah, para subjek tersebut kiranya telah dipertimbangkan dari segi karakteristik peserta diklat (kemampuan, motivasi, efikasi diri, dan orientasinya pada manfaat diklat). Pengumpulan data pada penelitian ini, tidak terbatas hanya pada subjek penelitian namun melibatkan juga sumber data lain yakni Kepala Sekolah/Madrasah dari para alumni.

Objek penelitian ini adalah transfer pelatihan alumni Diklat Teknis Substantif PTK BDK Denpasar. Bentuk transfer pelatihan disederhanakan dan difokuskan pada keberlanjutan proposal PTK yang telah disusun saat mengikuti Diklat, ditindaklanjuti secara serius sampai laporan tersusun lengkap dan diseminarkan.
Metode pengumpulan data dalam penelitian ini meliputi wawancara dan dokumentasi. Metode wawancara dilakukan dalam bentuk wawancara semi terstruktur, dilakukan melalui pertemuan langsung dan via telepon. Panduan wawancara digunakan untuk mengarahkan pertanyaan seputar bagaimana pemahaman alumni atas materi diklat dan orientasi manfaat diklat; langkah kerja dalam menyempurnakan proposal, melaksanakan siklus, mengolah data, membuat laporan, melaksanakan seminar hasil PTK; pemanfaatan laporan PTK yang telah diseminarkan untuk pemenuhan angka kredit; faktor pendukung dan penghambat dalam melakukan PTK. Demi lengkapnya data atau informasi yang diperoleh, penelitian ini juga menggunakan metode dokumentasi. Metode dokumentasi dimaksudkan untuk mengecek bukti fisik atas jawaban yang disampaikan oleh subjek penelitian, berkaitan dengan dokumen proposal, 
perangkat pelaksanaan siklus, hasil olah data, naskah laporan PTK.

Teknik analisis data yang digunakan dalam penelitian ini adalah teknik analisis data oleh Matthew B. Miles dan Michael Huberman. Teknik analisis ini terdiri atas tiga alur kegiatan yakni reduksi data, penyajian data, dan penarikan simpulan atau verifikasi, yang dilakukan bersamaan selama analisis data (Huberman, 1992:16). Reduksi data dalam penelitian ini dilakukan mulai dari pelaksanaan wawancara, yang mengarahkan pertanyaan dan pengumpulan data sesuai indikator transfer pelatihan yang telah dirumuskan. Hasil wawancara yang membutuhkan dukungan dokumen bukti fisik, langsung dikonfirmasi kepada informan yang bersangkutan untuk bisa menunjukkan kelengkapan dokumen dimaksud. Data melalui wawancara dengan para alumni ini, dikonfirmasi juga kepada kepala sekolah/madrasah yang bersangkutan perihal kebenarannya, yang bertujuan sebagai bentuk triangulasi data berdasarkan narasumber yang berbeda yakni alumni dan atasan langsung alumni. Penyajian data sebagai alur penting yang kedua dilakukan melalui interpretasi data hasil wawancara dan telaah dokumen, yang disajikan dalam bentuk deskriptif naratif. Berdasarkan deskripsi data pada masalah, kemudian ditarik suatu kesimpulan yang logis. Penarikan simpulan atau verifikasi dalam penelitian ini adalah membuat pertimbangan atau keputusan tentang gambaran transfer pelatihan alumni Diklat Teknis Substantif PTK.

\section{HASIL DAN PEMBAHASAN}

Dua kelompok alumni yakni alumni Diklat Teknis Substantif PTK Kantor Kementerian Agama Kota Denpasar dan alumni Diklat Teknis Substantif PTK Kantor Kementerian Agama Kabupaten Lombok Utara, menunjukkan aktivitas yang berbeda pasca diklat. Keempat puluh orang alumni di Kota Denpasar, secara keseluruhan serempak meminta bimbingan kepada Widyaiswara pengampu mata diklat inti melalui komunikasi via telepon, email, dan bahkan bertemu langsung. Wilayah Kota Denpasar yang masih berdekatan dan terjangkau dari lokasi kantor BDK Denpasar, memang sangat memungkinkan hal tersebut. Selain juga memang karena sudah ada komitmen bersama antara alumni dan Widyaiswara pengampu untuk serius merealisasikan RTL dalam bentuk pelaksanaan PTK sampai pada pembuatan laporan hasil. Namun demikian, saat keempat puluh alumni melaporkan realisasi pelaksanaan RTL ke BDK Denpasar, lambat laun komunikasi antara peserta dengan Widyaiswara (termasuk peneliti) semakin berkurang. Kelanjutan dari siklus yang menjadi tagihan RTL, tidak ditindaklanjuti kembali oleh seluruh peserta sampai ke pengolahan data dan laporan. Hanya 2 orang saja yang melanjutkannya termasuk salah satunya adalah SD. Berbeda hal dengan alumni di Kabupaten Lombok Utara, karena terpaut jarak maka hanya bisa melanjutkan komunikasi dan bimbingan via telepon dan email. Sehingga sedikit berpengaruh pada keseriusan alumni dalam merealisasikan RTL maupun melanjutkan sampai tuntas di pembuatan laporan PTK dan seminar hasil. NM dan WS adalah yang intensif meminta bimbingan kepada Widyaiswara termasuk peneliti (karena di kedua diklat tersebut, peneliti bertim dengan seorang Widyaiswara lain untuk mengisi mata diklat inti).

Berikut dijelaskan hasil penelitian berdasarkan kegiatan-kegiatan yang merupakan runutan kerja proses PTK yang sekaligus sebagai indikator dilakukannya transfer pelatihan oleh alumni Diklat Teknis Substantif PTK. Kegiatan-kegiatan sesuai dengan runutan kerja PTK tersebut meliputi penyempurnaan proposal PTK, pelaksanaan siklus, pengolahan data hasil PTK, pembuatan laporan, pelaksanaan seminar hasil PTK, dan pengusulan laporan PTK untuk pemenuhan kebutuhan angka kredit guru dari sub unsur publikasi ilmiah.

\section{Penyempurnaan proposal PTK}

Proposal yang peserta buat selama diklat sesungguhnya dapat dikatakan belum sempurna. Hari efektif belajar yang hanya 5 hari, ada 6 mata diklat yang harus dipelajari baik teori dan praktik, menjadikan waktu tersebut sangat singkat untuk menyelesaikan draf proposal maupun perangkat pelaksanaan siklus. Terbukti di saat pengumpulan hasil kerja di hari terakhir belajar, banyak peserta yang mohon permakluman untuk keterbatasan narasi. Peserta mengaku belum mampu 
mendeskripsikan komponen proposal PTK secara lengkap menggunakan narasi sendiri, lebih cenderung meniru narasi yang banyak dicontohkan oleh Widyaiswara.

Atas alasan tersebut maka alumni perlu mencermati dan menyempurnakan kembali draf proposal yang telah dibuat. Penyempurnaan dimaksudkan untuk pengetikan yang mungkin belum rapi ataupun penjelasan yang belum tepat atau lengkap. Intinya draf proposal perlu disempurnakan agar lebih maksimal baik isi maupun tulisan. Sehingga dapat menjadi acuan yang pasti untuk melangkah ke tahap penelitian selanjutnya yaitu pelaksanaan siklus.

Informasi yang peneliti peroleh dari ketiga informan, menyatakan bahwa memang setelah diklat usai barulah ketiganya bisa merapikan dan melengkapi draf proposalnya dengan lebih tenang dan tidak terburu-buru. Di sela jam mengajar, ketiganya banyak memperbaiki di bagian latar belakang, kajian teori, dan prosedur penelitian. Ketiga informan mengaku bahwa narasi latar belakang belum runut sepenuhnya sesuai kriteria minimal yang semestinya memuat kondisi riil atau kenyataan di kelas, kondisi pembelajaran yang ideal atau menjadi harapan, kesenjangan di antara 2 kondisi tersebut, serta satu alternatif tindakan yang menjadi solusi dalam PTK. Mereka sebenarnya paham dengan apa yang seharusnya muncul di latar belakang, hanya saja karena belum terbiasa menuangkan secara runut apa yang ada di pikiran dalam bentuk tulisan, maka latar belakang yang ada di draf semula masih apa adanya sesuai yang informan bisa tulis saat itu saja. Kajian teori pun hampir serupa, masih dituliskan apa yang bisa dituliskan saja. Artinya sebatas mengutip tapi belum mengikuti ketentuan yang baku. Teori-teori yang dicantumkan masih banyak yang mengambil dari blog-blog pribadi. Informan mengakui selain karena keterbatasan buku yang dibawa saat diklat, mereka juga belum paham cara efektif melakukan penelusuran di internet untuk menemukan referensi yang tepat. Bagaimana cara mengutip dan memasukkannya ke dalam daftar pustaka, serta batas maksimal tahun terbit referensi yang dirujuk. Setelah memperoleh penjelasan dari Widyaiswara dan ada waktu yang lebih luang di sela keseharian mengajar, barulah ketiga informan mencoba untuk melengkapinya. Perihal prosedur penelitian juga seperti itu. Setelah RPP siklus I dibuat dan disempurnakan sesuai langkah pembelajaran menggunakan tindakan yang dipilih, barulah narasi di bagian pelaksanaan siklus yang ada dalam proposal bisa dilengkapi.

Pada saat menyempurnakan proposal, informan terkadang menghubungi Widyaiswara (termasuk peneliti) melalui telepon atau email untuk mendiskusikan hasil pekerjaannya. Hal ini untuk memastikan bahwa langkah alumni sebagai peneliti sudah benar, sebelum lanjut ke tahap berikutnya yakni pelaksanaan siklus. Sudah tepatkah variabel masalah dan variabel tindakan yang dipilih, sudah tepatkah teori yang dirujuk, sudah sesuaikah instrumen yang disiapkan, dan benarkah langkah penerapan tindakan yang dipilih. Hal penting di sini adalah informan paham dengan segala ketentuan dalam penyusunan proposal PTK yakni berpedoman pada buku 4 Kegiatan PKB Guru dan Angka Kreditnya.

\section{Pelaksanaan siklus PTK}

Siklus akan dapat dilaksanakan jika perangkat yang dibutuhkan telah selesai disiapkan oleh guru. Jadi dari hasil kerja selama diklat, RPP yang sudah dibuat, lembar kerja, dan instrumen penelitian yang akan digunakan tetap perlu dicermati sekali lagi apakah sudah lengkap dan benar. Media yang akan digunakan juga perlu disiapkan. Ketiga informan menyatakan bahwa pembuatan instrumen yang berupa lembar observasi atas tindakan guru dan aktivitas peserta didik, tidak ada kendala. Mereka sudah memahami dan dapat membuatnya. Persiapan yang mereka lakukan banyak di penyempurnaan RPP, instrumen untuk mengukur hasil belajar, lembar kerja sesuai materi, dan media pembelajaran.

SD mengatakan bahwa dirinya banyak melakukan persiapan siklus mulai dari memperbaiki RPP terutama di langkah pembelajaran. Bagaimana pengelolaan pembelajaran yang menggunakan kartu remi agar tersaji jelas di RPP dan terbaca sebagai tindakan yang ditonjolkan atau sebagai solusi yang dipilih sebagai tindakan. SD juga menyiapkan instrumen untuk mengukur hasil belajar yang disesuaikan dengan materi keliling dan luas lingkaran. Selain itu SD membuat 
media berupa kartu remi. Lain halnya NM, banyak melakukan persiapan siklus terutama di penyempurnaan langkah pembelajaran yang mana akan menerapkan model pembelajaran mind mapping pada mata pelajaran Pendidikan Agama Islam dan Budi Pekerti kelas VII SMP. NM juga menyiapkan lembar kerja agar peserta didik lebih mudah memahami materi yang dibelajarkan. Lembar kerja tersebut ditujukan agar peserta didik dapat merangkum materi dan kemudian menyajikannya dalam sebuah peta konsep yang tepat dan menarik sesuai dengan model pembelajaran mind mapping yang dimaksud. Informan ketiga yakni WS, mengatakan bahwa persiapan yang dilakukan untuk pelaksanaan siklus di antaranya adalah menyempurnakan RPP disesuaikan dengan model pembelajaran kooperatif make a match dan materi tata cara salat. WS juga menyiapkan lembar kerja terbimbing yang disesuaikan dengan tingkat kemampuan peserta didik tingkat SD, kemudian menyiapkan instrumen penilaian untuk mengukur hasil belajar, serta media berupa poster-poster tentang tata cara salat dan pasangan kartu untuk permainan make a match.

Ketiga informan mengakui bahwa persiapan ini cukup menyita waktu terutama di pembuatan lembar kerja dan media pembelajaran. Sebelumnya para informan belum terbiasa membuat lembar kerja karena selama ini mereka terbiasa menggunakan lembar kerja yang dicetak oleh penerbit, yang hanya berisi latihan soal bukan lembar kerja yang membimbing kepada penemuan konsep. Sedangkan untuk media, kartu remi yang dibuat oleh SD juga dalam bentuk kartu yang memang dibuat menyerupai kartu remi baik tampilan dan penggunaannya dalam permainan. Media kartu yang dibuat oleh WS juga dirancang sedemikian rupa agar dapat dimainkan oleh 2 kelompok di kelas dan sesuai dengan substansi materi pelajaran setiap pertemuan.

Sesuai dengan teori yang telah dipelajari selama diklat, ketiga informan melaksanakan tindakan dalam 2 siklus di mana setiap siklus terdiri atas 2 kali pertemuan. SD dengan lokasi madrasahnya yang berada di Kota Denpasar, bisa memperoleh pendampingan dari Widyaiswara saat pelaksanaan siklus I. Sedangkan untuk siklus II dilanjutkan oleh SD secara mandiri. NM dan WS yang berlokasi di Lombok Utara, melaksanakan siklus I dan II secara mandiri tanpa pendampingan oleh Widyaiswara karena memang jarak Lombok Utara yang tidak memungkinkan untuk didatangi sewaktu-waktu. Namun NM dan WS tetap berkomunikasi via telepon, whatsapp, dan email selama pelaksanaan siklus tersebut.

\section{Pengolahan data hasil PTK}

Setelah siklus dilaksanakan, langkah berikutnya adalah pengolahan data hasil PTK. Data di siklus I dan II disajikan dalam rekapitulasi yang lebih bermakna sehingga dapat terbaca apakah ada peningkatan di tiap siklus dan sudah mencapai indikator kinerja yang ditetapkan atau belum. SD dan NM mengakui paham tentang cara pengolahan data tersebut. Sedangkan WS mengakui sedikit kesulitan karena saat diklat, praktik pengolahan data yang didapat masih sebatas contoh dan simulasi. WS dapat memahaminya setelah berdiskusi dengan Widyaiswara dan memperoleh arahan bagaimana cara mengolah data dimaksud. Bagaimana cara membaca peningkatan dan kemajuan dari peserta didik di setiap siklus, cara membandingkan hasil di setiap siklus dengan indikator kinerja yang menjadi target keberhasilan tindakan, baru benar-benar bisa dipahami WS setelah memperoleh data hasil PTK yang riil sesuai miliknya. Artinya WS mengakui bahwa penjelasan saat diklat hanya sekedar dipahami saat itu saja dan WS tidak ingat atau paham bagaimana menerjemahkan ke pengolahan sesungguhnya.

\section{Pembuatan laporan}

Pembuatan laporan,
penulisan bab IV, idealnya
dilakukan bersamaan saat olah data siklus I maupun siklus II. Peneliti tidak perlu menunggu siklus II selesai baru kemudian mulai menulis deskripsi bab IV. Karena sifatnya seperti ibarat orang bercerita, peneliti dalam PTK harus bisa mendeskripsikan secara detail bagaimana situasi yang terjadi di setiap pertemuan dalam siklus. Deskripsi tersebut didukung oleh data capaian peserta didik sebagaimana hasil dalam olah data. Jadi supaya tidak ada situasi yang lupa dideskripsikan, peneliti langsung mendeskripsikan hasil siklus I di saat proses 
pengolahan data siklus I sedang berjalan. Begitu juga hasil siklus II, langsung dideskripsikan di saat proses pengolahan data siklus II sedang berjalan.

Ketiga informan mengakui telah melakukan hal tersebut. Hanya memang ketiganya mengakui terkendala di pembuatan deskripsi atau narasi dimaksud. Ketiganya mengakui belum terbiasa menulis, sehingga menghabiskan waktu yang cukup panjang saat menuliskan bab IV. Menurut SD, penulisan bab IV dan $\mathrm{V}$ ini perlu latihan dan bimbingan Widyaiswara secara khusus agar sesuai dengan ketentuan yang ada. SD sendiri sempat mengirimkan draf bab IV dan V melalui email untuk dikoreksi peneliti. Saat itu tepatnya bulan Mei 2017. Jadi SD yang lebih intensif meminta bimbingan sampai ke pelaporan. NM dan WS tidak demikian. NM menganggap contoh dan penjelasan yang diterima saat diklat sudah cukup jelas. NM lebih berinisiatif untuk mencari dan mempelajari contoh-contoh laporan PTK terdahulu. Contoh-contoh tersebut diakui NM banyak menginspirasi tentang bagaimana menuangkan hasil interpretasi data ke dalam narasi laporan. NM tidak merasakan kesulitan yang begitu berarti dalam penulisan laporan. Hanya memang sedikit terkendala dengan aktivitas mengajar yang cukup padat. Tetapi di benak NM, selagi masih hangat dalam ingatan, lebih baik untuk menyelesaikan laporan tersebut dengan segera. Akhirnya laporan tersebut pun selesai di bulan Maret 2018. Hampir sama dengan NM, WS juga menyelesaikan laporannya secara mandiri tanpa konsultasi yang intensif dengan Widyaiswara termasuk peneliti. WS memang mengalami kebingungan, tapi dari contoh-contoh yang dipelajari tetap terus mencoba dan akhirnya dapat menyelesaikan laporan di bulan Juni 2018.

\section{Pelaksanaan seminar hasil PTK}

Melalui komunikasi via telepon bulan Agustus, Oktober dan terakhir awal Desember 2018, peneliti sempat menanyakan bagaimana draf bab IV yang telah dikoreksi peneliti apakah sudah ditindaklanjuti oleh SD. SD mengatakan saat itu sudah langsung direvisi sesuai catatancatatan koreksi namun sampai awal Desember 2018 belum membukanya kembali untuk siap diseminarkan. SD mengatakan terkendala dengan kesibukan tugas tambahan di madrasahnya yaitu menjabat sebagai Wakil Kepala bagian Kurikulum. Tetapi SD menyatakan kepada peneliti akan mengusahakan seminar paling lambat akhir Desember 2018 supaya hasil kerjanya tersebut tidak sia-sia. SD menyadari sepenuhnya bahwa kelanjutan proses tersebut sampai ke tahap seminar sebenarnya lebih ke tanggung jawab pribadi, bukan karena dipersulit oleh pihak madrasah ataupun pimpinan, tapi justru yang bersangkutan sendiri yang belum bisa mencapai target sampai tuntas.

Pengakuan SD tersebut sejalan dengan informasi yang peneliti peroleh dari Kepala Madrasah. Kepala Madrasah mengatakan bahwa berdasar pengamatan, penguasaan materi oleh SD tidak ada kendala. Siklus PTK sudah berhasil dilaksanakannya, olah data juga sudah dilakukan, penyusunan laporan hampir selesai. Kepala Madrasah tinggal menunggu draf laporan lengkapnya. Menurut Kepala Madrasah, kesanggupan SD untuk menyelesaikan laporan sedikit terkendala pada pengelolaan beban kerja. Meskipun hal ini juga dimaklumi oleh Kepala Madrasah, menurutnya hal ini ikut disebabkan oleh pengalaman belajar saat diklat yang belum cukup komprehensif. Materi pengolahan data dan penyusunan laporan hanya sebatas contoh atau simulasi saja. Alumni sangat perlu mengembangkan kemampuan dan pemahamannya secara lebih lagi agar dapat menyusun laporan sesuai hasil interpretasi data masing-masing. Seyogyanya hal ini kembali ke tekad dan usaha alumni. Kepala Madrasah sebatas memberi dukungan baik motivasi maupun fasilitas yang dimungkinkan.

Jika SD belum sampai pada tahap seminar, berbeda halnya dengan NM. NM yang justru tidak terlalu banyak berkonsultasi saat penyusunan laporan, berhasil melaksanakan seminar di akhir bulan Maret 2018. NM mengakui dukungan sekolah baik teman guru maupun Kepala Sekolah, sangat baik sehingga tidak terkendala sama sekali di pelaksanaan seminar. Sedangkan lain hal yang terjadi dengan WS. Sampai awal Desember 2018, WS menginformasikan belum melaksanakan seminar. WS mengatakan di sekolahnya sempat terjadi pergantian Kepala Sekolah sehingga ijin 
penelitian dan kelanjutan proses ke seminar sedikit sulit dikomunikasikan dengan Kepala Sekolah pengganti. Ijin saja tidak turun apalagi bisa difasilitasi. Konsultasi dengan pengawas sekolah pun kurang lancar. Jadi WS mengatakan sulit mendapat dukungan untuk bisa melaksanakan seminar tersebut.

\section{Pengusulan laporan PTK}

Sesuai penjelasan pada bagian sebelumnya, karena SD dan WS belum melaksanakan seminar, tentunya belum dilakukan pengusulan angka kredit dari laporan hasil PTK tersebut. Sedangkan NM yang sudah melaksanakan seminar, sudah langsung mengusulkan laporan hasil PTK yang dimilikinya untuk kebutuhan naik pangkat. NM memanfaatkan laporan hasil PTK yang bernilai 4 tersebut untuk naik pangkat dari III/c ke III/d.

Keberhasilan yang dicapai oleh NM tidak lepas dari semangat atas komitmennya untuk menghasilkan karya dalam bentuk laporan PTK jadi. Menurut NM bahwasanya akan sangat disayangkan jika apa yang telah dipelajari dan dikerjakan selama diklat tidak ditindaklanjuti setelah kembali ke tempat tugas. Pengalaman melakukan PTK seutuhnya baru akan diperoleh jika proposal ditindaklanjuti melalui pelaksanaan siklus sampai ke pengolahan data dan pelaporan bahkan sampai ke seminar. Jadi jelas bahwa peserta Diklat Teknis Substantif PTK akan lebih merasakan manfaat diklat jika telah menyelesaikan seluruh proses tersebut.

Berdasarkan hasil penelitian di atas, tampak bahwa transfer pelatihan yang dilakukan oleh masing-masing alumni memiliki capaian target dan waktu penyelesaian yang berbeda. Waktu dari selesainya diklat sampai bisa disusunnya laporan PTK oleh ketiga informan tampak berbeda. SD menyelesaikan dalam waktu 4 bulan (Februari sampai dengan Mei 2017), NM dalam waktu 6 bulan (Oktober 2017 sampai dengan Maret 2018), dan WS dalam waktu 9 bulan (Oktober 2017 sampai dengan Juni 2018). Namun itupun baru sampai di pelaporan, yang berhasil sampai ke pelaksanaan seminar hanyalah NM. Sampai dengan awal Desember 2018, SD baru berencana akan melaksanakan seminar, sedangkan WS belum ada kejelasan. Rentang waktu tersebut sudah melewati 1 tahun dari waktu pelaksanaan diklat. Lambat laun alumni kembali dengan rutinitas tugas kesehariannya. Semangat mengimplementasikan hasil diklat sudah semakin berkurang. Artinya, kecil harapan bagi SD dan WS untuk memenuhi target sampai ke pelaksanaan seminar hasil PTK.

Transfer pelatihan efektif terlaksana segera setelah diklat selesai. Adapun kemungkinannya bisa jadi 6 bulan setelah diklat atau maksimal 1 tahun setelah diklat. Selebihnya dari 1 tahun, kecil harapan transfer pelatihan terlaksana secara maksimal. Target RTL yang mewajibkan laporan realisasi maksimal 2 minggu setelah diklat usai, memperkuat fakta bahwa sebagian besar alumni giat melakukan transfer pelatihan segera setelah diklat, dan mulai berguguran setelah lewat masa 3 atau 6 bulan ke atas.

Faktor apa yang kiranya mempengaruhi hal tersebut, kemungkinan yang pertama adalah penguasaan pengetahuan dan keterampilan oleh alumni. Seperti yang telah diungkap di mana SD mengaku masih perlu penguatan untuk materi penyusunan laporan PTK dan WS yang perlu penguatan di materi pengolahan data dan penyusunan laporan PTK. Pemahaman dan kemampuan alumni dalam menerjemahkan apa yang telah dipelajari disandingkan dengan kebutuhan dan kondisi di lingkungan kerja masing-masing, berpengaruh pada kelancaran pelaksanaan transfer pelatihan. Seperti yang terjadi pada SD, mandek di awal Mei 2017 karena ragu dan belum paham betul cara mendeskripsikan sub bab B, C, dan D di bab IV laporan. Setelah mendapat arahan dari Widyaiswara, barulah kemudian melanjutkan sampai sub bab terakhir sehingga bab IV dan V pun selesai di akhir Mei 2017.

Faktor kedua adalah efikasi diri masingmasing alumni. Lihat kembali SD, akhir Mei 2017 sudah dapat menyelesaikan draf laporan sampai pada bab V. Namun sampai dengan awal Desember 2018 ternyata SD belum menata kembali draf laporan Bab I-V untuk dilengkapi bersama lampirannya. Akibatnya SD pun belum sampai pada tahapan seminar. Melalui percakapan non formal antara peneliti dan SD, dapat ditangkap bahwa SD kurang yakin laporan PTK miliknya layak untuk 
diseminarkan. Padahal syarat seminar pun sebenarnya tidak ada yang memberatkan. Prinsipnya seminar dihadiri minimal oleh 15 orang guru dan 3 sekolah di sekitar yang sejenjang. Hal yang hampir serupa juga terjadi pada WS. Keyakinan WS untuk dapat menyelesaikan laporan PTK tidak seteguh keyakinan NM yang sama-sama di Lombok Utara. WS baru dapat menyelesaikannya dalam waktu 9 bulan. Untuk pelaksanaan seminar pun WS kembali ragu-ragu apakah dirinya layak untuk menyajikan laporan hasil PTK tersebut dalam sebuah seminar. Dari gambaran situasi ini, tentu terbaca bahwa selain efikasi diri alumni, ada faktor lain yang ikut berpengaruh pada kesuksesan transfer pelatihan, yakni dukungan atasan atau lingkungan kerja. Karena sudah terbukti di lain pihak, NM berhasil melaksanakan seminar dikarenakan adanya dukungan penuh dari Kepala Sekolah maupun Pengawas Sekolah. Melalui dukungan pengkondisian oleh Kepala Sekolah, dengan prinsip syarat minimal seminar terpenuhi, maka seminar hasil PTK NM berhasil dilaksanakan. Dukungan atasan dan lingkungan kerja ini menyiratkan makna bahwa kesempatan juga menjadi penting adanya. Kesempatan akan terbuka luas di saat ada dukungan sepenuhnya dari atasan selain situasi kondusif juga terbangun di lingkungan kerja.

Selain faktor internal dalam diri alumni yang meliputi kemampuan, motivasi, efikasi diri, kesadaran pentingnya diklat yang diikuti, ada faktor eksternal berupa dukungan di lingkungan kerja dan dukungan dari BDK Denpasar, yang ikut mempengaruhi transfer pelatihan alumni diklat. Artinya, dukungan dan kontrol dari BDK Denpasar sebagai penyelenggara, seyogyanya tetap dibutuhkan untuk mengoptimalkan transfer pelatihan alumni diklat dimaksud. Sebagaimana yang telah diungkap, mulai dari penyempurnaan proposal, pelaksanaan siklus, pengolahan data, penyusunan laporan, dan pengusulannya angka kredit, akan lebih sempurna jika terawasi dan dibimbing oleh Widyaiswara. Mengapa demikian? Bisa saja proses tersebut sudah hampir di ujung target seperti di penyusunan laporan, tapi bisa jadi tidak mencapai tahap seminar karena tidak ada motivasi ataupun yang memberi pencerahan bahwasanya seminar itu tidak sulit ataupun rumit. Bisa saja karena ketidaktahuan, transfer pelatihan yang tinggal selangkah lagi, tidak dapat diselesaikan oleh alumni. Atau bisa juga baru lanjut ke pelaksanaan siklus, tetapi karena tidak paham apa yang harus diperbuat selama siklus, menyebabkan alumni mandek atau menghentikan langkah kerjanya.

Umumnya PTK bukan hal asing atau baru bagi guru. Hanya saja kemauan dan pemahaman tentang prosedur PTK yang benar, penyusunan laporan yang tepat dengan sistematika yang mengacu pada pedoman baku, masih perlu diluruskan atau dikuatkan. Seluruh guru yang mengikuti Diklat Teknis Substantif PTK telah menyadari akan arti penting Diklat tersebut. Di samping mendorong pada peningkatan kualitas pembelajaran, Diklat Teknis Substantif PTK mengingatkan bahwa ada kebutuhan guru untuk melaksanakan penelitian sebagai tuntutan di karir kepangkatannya.

Dengan demikian, agar transfer pelatihan ini tidak hanya menjadi formalitas ataupun tidak berdampak apa-apa bagi alumni, penting kiranya BDK Denpasar melalui Widyaiswara mengupayakan pembimbingan peserta pasca diklat terutama pada rentang waktu di bawah 6 bulan dari selesai diklat. Pemahaman dan keterampilan yang didapat peserta saat diklat tetap perlu penguatan untuk dapat dipraktikkan melalui penyesuaian di lingkungan kerja. Kemampuan dan kemauan saja tidak cukup karena kedua hal tersebut akan melemah seiring waktu jika tidak terus diasah. Untuk itu motivasi dan keyakinan akan kemampuan menyelesaikan sesuai target, perlu ditumbuhkan dalam diri alumni ataupun dibangkitkan melalui bimbingan Widyaiswara.

\section{PENUTUP}

Berdasarkan paparan hasil penelitian dan pembahasan maka dapat disampaikan simpulan bahwa transfer pelatihan oleh alumni Diklat Teknis Substantif PTK BDK Denpasar dapat berupa kelanjutan proposal yang dibuat selama Diklat. Transfer pelatihan dipengaruhi oleh karakteristik peserta Diklat (meliputi kemampuan kognitif, motivasi, efikasi diri, dan orientasi manfaat Diklat), desain pelatihan, dan lingkungan kerja. Pada praktiknya ada yang melaksanakannya segera setelah Diklat (kurang 
dari atau sampai dengan 6 bulan) dan ada yang sampai 1 tahun. Untuk ini, perlu dikondisikan agar RTL terlaksana secara sempurna dan terus lanjut sampai ke pelaksanaan seminar hasil PTK.

Sejalan dengan simpulan penelitian, peneliti menyampaikan beberapa rekomendasi sebagai berikut. BDK Denpasar hendaknya lebih menggiatkan transfer pelatihan oleh para alumni diklat Teknis Substantif PTK tidak sebatas realisasi RTL tetapi sampai pada penyusunan laporan PTK. Widyaiswara hendaknya tetap memberi bimbingan dan motivasi kepada alumni untuk menerapkan pengetahuan dan keterampilannya dalam melaksanakan transfer pelatihan demi memperoleh pengalaman dan keterampilan yang utuh dalam melaksanakan PTK. Stakeholder/user di wilayah kerja hendaknya menindaklanjuti upaya pemberdayaan kompetensi dan keterampilan alumni pasca diklat sesuai konteks diklat yang telah diikuti.

\section{DAFTAR PUSTAKA}

Ardaneswari, C.P. (2016) 'Transfer of Training (Analisis Pelaksanaan Transfer of Training di Badan Kepegawaian Daerah (BKD) Daerah Istimewa Yogyakarta)', NATAPRAJA: Jurnal Kajian Ilmu Administrasi Negara, 4(2). Tersedia pada: https://journal.uny.ac.id/index. php/natapraja/article/download/12622/8 907 (Diakses: 16 Juli 2018).

Baldwin, T.T. and Ford, J.K. (1988) 'Transfer of Training: A Review And Direction For Future Research', Personnel Psychology. doi: 10.1111/j.17446570.1988.tb00632.x.

Depdiknas (2007) Peraturan Menteri Pendidikan Nasional Republik Indonesia Nomor 16 Tahun 2007 tentang Standar Kualifikasi Akademik dan Kompetensi Guru, Lampiran nomor 18 tentang Standar Kompetensi Guru Mata Pelajaran di SD/MI, SMP/MTs, SMA/MA, dan SMK/MAK, Jakarta. Indonesia.

Grossman, R. \& Salas, E. (2011) 'The transfer of training: what really matters', International Journal of Training and
Development, 15(2). Tersedia pada: https://formation-syndicale.ftq.qc.ca/ wp-content/uploads/sites/5/2019/04/ Grossman_et_al-2011-International_ Journal_of_Training_and_Developmen t.pdf (Diakses: 15 Agustus 2018).

Hariyanto, E., Purnomo, R. and Bawono, I. R. (2011) 'Desain Pelatihan, Dukungan Organisasional, Dukungan Supervisor dan Self-Efficacy sebagai Faktor Penentu Keefektifan Transfer Pelatihan', Jurnal Siasat Bisnis. doi: 10.20885/jsb.vol15.iss2.art5.

Hastari, T. M. (2013) 'Studi Deskriptif tentang Learning Transfer bagi Alumni Peserta Pendidikan dan Pelatihan Pelayanan Publik oleh Badan Pendidikan dan Pelatihan Jawa Timur di Badan Koordinasi Malang', Jurnal Kebijakan dan Manajemen Publik, (1)1. Tersedia pada: http://journal.unair.ac.id/down load-fullpapers-14\%20Theresia_KMP $\% 20 \mathrm{~V} 1 \% 20 \mathrm{~N} 1 \% 20 \mathrm{Jan}-$ April\%202013.pdf (Diakses: 11 Juli 2018).

Kemenag (2015) Peraturan Menteri Agama Republik Indonesia Nomor 75 Tahun 2015 tentang Penyelenggaraan Pendidikan dan Pelatihan Pegawai pada Kementerian Agama, Jakarta. Indonesia.

Kimbal, D. A. (2015) Pengaruh Self Efficacy, Lingkungan Kerja, dan Dukungan Atasan terhadap Transfer Pelatihan pada Karyawan Bank Pembangunan Daerah (BPD) Bali Cabang Renon. Fakultas Ekonomi dan Bisnis, Universitas Udayana Denpasar.

Miles, M. B. \& Huberman, A.M. (1992) Qualitative Data Analysis. London: Sage Publication.

Pusdiklat Tenaga Teknis Pendidikan dan Keagamaan Badan Litbang dan Diklat Kementerian Agama RI (2018) Petunjuk Teknis Penyelenggaraan Diklat Tenaga Teknis Pendidikan dan Keagamaan, Jakarta. Indonesia. 
Saks, A. M. (2002) So what is a good transfer of training estimate? A reply to Fitzpatrick. Tersedia pada: https://www.researchgate.net/profile/Al an_Saks/publication/239769006_So_W hat_is_a_Good_Transfer_of_Training Estimate_A_Reply_to_Fitzpatrick/links 1556f083808aeccd7774106f7.pdf (Diakses: 17 Juli 2018)

Saks, A. M. and Burke, L. A. (2012) 'An investigation into the relationship between training evaluation and the transfer of training', International Journal of Training and Development. doi:

$10.1111 / \mathrm{j} .1468$
Sugiyono

(2011) Metode Penelitian Pendidikan: Pendekatan Kuantitatif, Kualitatif, dan R\&D. Bandung: Alfabeta.

Wahyuningtyas, N. \& Ratnawati, N. (2018) 'Pelatihan dan Pendampingan Penulisan Artikel Jurnal bagi Guru-Guru IPS Kabupaten Malang', JPDS: Jurnal Praksis dan Dedikasi Sosial, 1(1). Tersedia pada: http://journal2.um.ac.id/index.php/jpds/ article/download/3466/2238 (Diakses: 17Juli 2019) 2419.2011.00397.x. 